慶應義塾大学学術情報リポジトリ

Keio Associated Repository of Academic resouces

\begin{tabular}{|c|c|}
\hline Title & Lysophospholipase $\mathrm{L}_{1}$ from escherichia coli K-12 overproducer \\
\hline \multicolumn{2}{|l|}{ Sub Title } \\
\hline Author & $\begin{array}{l}\text { 唐沢，健(Karasawa, Ken) } \\
\text { 工藤, 一郎(Kudo, Ichiro) } \\
\text { 小林, 哲幸(Kobayashi, Tetsuyuki) } \\
\text { 本間, 浩(Honma, Hiroshi) } \\
\text { 知場, 伸介(Chiba, Nobuyoshi) } \\
\text { 水島, 洋(Mizushima, Hiroshi) } \\
\text { 井上，圭三(Inoue, Keizo) } \\
\text { 野島，庄七(Nojima, Shoshichi) }\end{array}$ \\
\hline Publisher & 共立薬科大学 \\
\hline Publication year & 1991 \\
\hline Jtitle & $\begin{array}{l}\text { 共立薬科大学研究年報 (The annual report of the Kyoritsu College of } \\
\text { Pharmacy). No.36 (1991. ) ,p.60-60 }\end{array}$ \\
\hline \multicolumn{2}{|l|}{ JaLC DOI } \\
\hline \multicolumn{2}{|l|}{ Abstract } \\
\hline Notes & 抄録 \\
\hline Genre & Technical Report \\
\hline URL & $\begin{array}{l}\text { https://koara.lib.keio.ac.jp/xoonips/modules/xoonips/detail.php?koara_id=AN00062898-0000003 } \\
\text { 6-0060 }\end{array}$ \\
\hline
\end{tabular}

慶應義塾大学学術情報リポジトリ(KOARA)に掲載されているコンテンツの著作権は、それぞれの著作者、学会または出版社/発行者に帰属し、その権利は著作権法によって 保護されています。引用にあたっては、著作権法を遵守してご利用ください。

The copyrights of content available on the KeiO Associated Repository of Academic resources (KOARA) belong to the respective authors, academic societies, or publishers/issuers, and these rights are protected by the Japanese Copyright Act. When quoting the content, please follow the Japanese copyright act. 
No. $36 \quad 1991$

\title{
Lysophospholipase $\mathrm{L}_{1}$ from Escherichia coli K-12 Overproducer
}

\author{
Ken Karasawa***, Ichiro Kudo**, Tetsuyuki Kobayashi*****, Hiroshi Homma, \\ Nobuyoshi Chiba**, Hiroshi Mizushima****, Keizo Inoue**, \\ and Shoshichi Nojima***
}

唐沢 健 ${ }^{* * *}$, 工藤一郎**, 小林哲幸*****, 本間 浩, 知場伸介**,

水島 洋****, 井上圭三**, 野島庄七***

After screening $900 \mathrm{E}$. coli strains of the Clarke and Carbon collection for by lysophospholipase $\mathrm{L}_{1}$ activities, we isolated a clone bearing the plasmid pLC6-34, which showed an increased level of lysophospholipase $\mathrm{L}_{1}$ activity. Strains bearing the plasmid $\mathrm{pC} 124$, a subclone of $\mathrm{pLC6}-34$ in plasmid vector $\mathrm{pUC8}$, showed approximately 11.4 times higher lysophospholipase $\mathrm{L}_{1}$ activity than that of the parental strain. Starting from those overproducing strains, the lysophospholipase $\mathrm{L}_{1}$ was purified to near homogeneity by sequential use of ammonium sulfate fractionation, Sephacryl S-300, DEAE-cellulose, hydroxyapatite and Sephacryl S-200 column chromatographies. The apparent molecular weight of the purified lysophospholipase $L_{1}$ was estimated to be $20,500-22,000$ both by SDS-polyacrylamide gel electrophoresis and by gel permeation chromatography. The specific activity of the homogeneous lysophospholipase $L_{1}$ was $10,400 \mathrm{nmol} / \mathrm{min} / \mathrm{mg}$ protein when 1-acyl-sn-glycero-3-phosphoethanolamine was used as the substrate. The amino acid sequence of the amino-terminal portion of purified lysophospholipase $\mathrm{L}_{1}$ was determined and was different from that of lysophospholipase $\mathrm{L}_{2}$, which had previously been purified from the envelope fraction of $E$. coli strains bearing its cloned structural gene, pldB (Karasawa, K., Kudo, I., Kobayashi, T., Sa-eki, T., Inoue, K., \& Nojima, S. (1985) J. Biochem 98, 1117-1125]. The gene responsible for overproduction of lysophospholipase $\mathrm{L}_{1}$ activity was designated as $p l d C$ (phospholipid degradation $C$ ). Its restriction enzyme map was also different from that of cloned $p l d B$. These results further confirmed that, in $E$. coli, there are two lysophospholipases with distinct characteristics.

* 本報告はJ. Biochem., 109, 288一293（1991）に発表.

** 東京大学薬学部

*** 帝京大学薬学部

**** 国立ガンセンター研究所生物物理部

****** 名古屋市立大学薬学部 